\title{
Effect of military expenditure on economic growth: evidences from India Pakistan and China using cointegration and causality analysis
}

Mohammad Hasan Raju ${ }^{1}$ and Zobayer Ahmed ${ }^{2^{*}}$

* Correspondence: ecozobayer@ gmail.com

${ }^{2}$ Faculty, Department of Economics \& Banking, International Islamic University Chittagong, Chattogram, Bangladesh

Full list of author information is available at the end of the article

\begin{abstract}
The study revisited the existing evidences of India Pakistan and China with updated data on the effect of military expenditure on economic growth. Econometric approaches analyzed the short and long run relationship between GDP growth and Military expenditure. Empirical studies have been done using cointegration analysis and causality test to justify the relationship and causality of the variables.

Interestingly, study obtained positive log-run relation, no short run relationship and unidirectional long run causality in every cases, but for different degrees of relationship. Obtained results are robust and passed necessary diagnostic tests significantly.
\end{abstract}

Keywords: Peace economics, GDP growth, Military expenditure

\section{Introduction}

Over the past decades the study of relationship between military expenditure and GDP growth has received extensive amount of attention of the researchers and policy makers around the world. This kind of attention has got more attention when different researchers obtained different result, for example (Smith and Smith 1980) argued that military expenditure protects countries from external threats and encourages foreign investment. By contrast, (Deger and Smith 1983) argued on negative effect on economic growth since it transfers resources from the civilian to the defense sector. Additionally, some other studies argued on no evidence of any relationship between military expenditure and economic growth such as (Adams et al. 1991; Alexander 1990; Ram 1986; Park 1993).

The keenness of the researchers on peace economics is valid as the military expenditure is one of the major concerns for countries irrespective of its developing status. Pulling out resources from most productive sector to ensure security could affect the annual net effect on the economy. By contrast, overlooking internal and external security to maximize net outputs of some productive sectors could also make the economy's flow unstable. Therefore, an empirical investigation is needed to draw a calculation.

(C) The Author(s). 2019 Open Access This article is distributed under the terms of the Creative Commons Attribution 4.0 International License (http://creativecommons.org/licenses/by/4.0/), which permits unrestricted use, distribution, and reproduction in any medium, provided you give appropriate credit to the original author(s) and the source, provide a link to the Creative Commons license, and indicate if changes were made. 
To justify the contribution of military expenditure, researchers have been working for under developed, developing, and developed countries. From the beginning, this kind of studies is more precise for the countries that have achieved their sovereignty from the neighbor countries and the countries who have political consent with other countries (Farzanegan 2014). So the aim of this study is to justify the relationship between military expenditure and economic growth for three neighbor countries that have to maintain a great amount of military budget as they are geographically correlated with one another.

\section{Literature review}

As military expenditure is an integral part of government expenditure researchers around the world were much curious to investigate the contribution of the military spending in the economy and this curiosity will be continued. From the beginning period to this present period many researchers have done their research and got some valuable findings that ultimately enriched the field of peace economy.

A number of researchers got positive relationship between military expenditure and economic growth. Researcher Asseery (1996) provided a robust evidence for Iraq that there is long run causality between military expenditure and economic growth and the economic growth is heavily dependent on military expenditure, he provided his empirical evidence using Cointegration analysis and ganger causality test. In 1973 and 1978 (Benoit 1973, 1978) proved that military spending increases literacy rate, medical facilities, employment opportunities, scientific and technological innovations. Atesoglu (2002) also used a Cointegration analysis for united states and gained positive and quantitative effect of military expenditure on economic growth. Following that, (Kollias et al. 2004b) examined the relationship between military expenditure and economic growth applying causality approach and acquired bi-directional causality between military spending and growth from 1964 to 1999. In 2004 (Kollias et al. 2004a) observed the relationship between military spending and economic growth among EU 15 countries using Cointegration analysis and causality test for the period of 1961-2000, almost all cases they got positive causality from economic growth to military spending and not vice-versa. They also concluded that the EU countries decide the military expenditure considering their economic status. To justify the relationship of military expenditure and economic growth for 65 countries from 1975 to 2004 (Dicle and Dicle 2010) run the causality approach and finally they obtained bidirectional positive causality between the variables in 54 of the 65 countries. In 2001 (Dakurah et al. 2001) proved that in 23 countries there is a unidirectional causality from military expenditure to economic growth or vice versa and bidirectional causality in 7 countries. Abu-qarn (2010) in 2010 studied the Arab Arab-Israel conflict but he did not find any persistent adverse impact of military expenditures on economic growth. Feridun et al. (2011) investigated the relationship of the military spending-growth for the case of North Cyprus from 1977 to 2007. Their study obtained a strong, positive unidirectional causality running from military expenditures to economic growth. Yildirim et al. (2005) examined the effect of military spending on economic growth in a panel of Middle Eastern countries and Turkey. Their study employed a dynamic panel data (1989-1999) estimation method and found positive growth effects of military expenditure. 
The other group of researchers got negative growth effect of military expenditure through different aspects such as higher budget deficit, higher public debt, higher rate of tax, lower capital formation, investment, and productivity of private sector, lower saving rate, decrease the spending of education, health, research and development. (Ball 1983; Deger 1986; Faini et al. 1984; Lim 1983; Ram 1995; Dunne and Vougas 1999; Gupta et al. 2001; and Dunne et al. 2002) all of the studies obtained the negative growth effect of military expenditure.

Additionally, some other research also concluded that there is no sufficient relationship between military expenditure and economic growth, some of them are (Adams et al. 1991; Alexander 1990; Ram 1995; Park 1993). According to them military expenditure does not have any significant impact on the economic growth as the spillover effect being highlighted by the proponents of the military spending is indistinct. Moreover, the idea that it crowd out private investment is not obvious.

In recent time there are some studies have taken place in South Asia which obtained positive growth effect. In 2013 (Shahbaz et al. 2013) got unidirectional causality from military spending to economic growth for Pakistan using the autoregressive distributive lag bounds testing approach to Cointegration. The authors (Khalid and Mustapha 2014) got positive relationship for India using ARDL model and ganger causality test, they found that $1 \%$ increase in military expenditure increases real GDP by $0.04 \%$ in short run but in long run the correlations are inconclusive. Chen (1993) conducted an empirical econometric analysis based on a Barro-style growth model for china, his findings support the existence of a single long-run equilibrium relationship between the variables.

\section{The data}

Principally, two variables are used in this analysis for three countries. We used the data of GDP growth as the indicator of economic growth and data of military expenditure as percentage of GDP as the value of military expenditure. To ensure the robustness of the studies we included possible maximum number of observations for each country. The data of GDP growth rate is collected from the World Bank Data; (June 10, 2018) and the data of Military expenditure as a percent of GDP are collected from Stockholm International Peace Research Institute (SIPRI-2018). Collected data ranges for India (1980-2017), for Pakistan (1989-2017), and for China (1989-2017).

\section{Econometrical process}

Study conducted econometrical analysis to investigate the relationship between GDP growth and military expenditure for the three lions of south asia, India, Pakistan, and China. Firstly, we tested the unit root of our variables using ADF test (Augmented Dickey Fuller). Secondly, to investigate the long-run relationship between GDP growth and military expenditure we used Engle-Ganger Cointegration test. Thirdly, to justify the direction of the causality we relayed on Ganger Causality test. Finally, a number of popular diagnostic tests have been done to rationalize the findings.

\section{Unit root test}

We employed widely used unit root test the Augmented Dickey-Fuller (ADF) to conclude the level of integration of the variables under analysis, and got the variables of each country are stationary at first difference $I(1)$. 
Table 1 Result of Cointegration test India

\begin{tabular}{llll}
\hline Hypothesized No of CE & Trace Statistics & Critical Value & Probability \\
None & 28.4348 & 25.8721 & 0.0235 \\
At most 1 & 8.97831 & 12.5179 & 0.1817 \\
Hypothesized No of CE & Max-Eigen Statistics & Critical Value & Probability \\
None & 19.4565 & 19.3870 & 0.0489 \\
At most 1 & 8.97831 & 12.5179 & 0.1817 \\
\hline
\end{tabular}

According to the result shown in the Table 1 at $5 \%$ level of significance we can reject the null hypothesis that "there is no Cointegration in this model" in both trace test and maximum-eigen value test. Both tests also indicate that there is 1 cointegrated equation at $5 \%$ level of significance, which is also supported by our test of significance with (0.000) $p$-value. So we can assure that there is long-run positive $\{1.215$ (Eq. 1) $\}$ relationship between variables.

\section{Causality test under VECM- India equations}

$$
\begin{gathered}
\Delta \mathrm{GDP}_{\mathrm{t}}=\alpha+\beta_{1}+(1.215) \mathrm{MILE}+e_{t} \\
\Delta \mathrm{GDP}_{\mathrm{t}}=\alpha+\sum_{\mathrm{i}=1}^{\mathrm{m}} \beta_{\mathrm{i}} \Delta \mathrm{GDP}_{\mathrm{t}-\mathrm{i}}+\sum_{\mathrm{i}=1}^{\mathrm{n}} \gamma_{\mathrm{i}} \Delta \mathrm{MILE}_{\mathrm{t}-\mathrm{i}}+\delta \mathrm{ECT}+\mathrm{u}_{\mathrm{t}} \\
\Delta \mathrm{MILE}_{\mathrm{t}}=\alpha+\sum_{\mathrm{i}=1}^{\mathrm{q}} \zeta_{\mathrm{i}} \Delta \mathrm{MILE}_{\mathrm{t}-\mathrm{i}}+\sum_{\mathrm{i}=1}^{\mathrm{s}} \lambda_{\mathrm{i}} \Delta \mathrm{GDP}_{\mathrm{t}-\mathrm{i}}+\phi \mathrm{ECT}+\mathrm{u}_{\mathrm{t}}
\end{gathered}
$$

Here Eq. (2) tests the causality from military expenditure to GDP and the Eq. (3) tests the causality from GDP to military expenditure for India.

We have jointly tested $\sum_{i=1}^{n} \gamma_{i} M_{1 L E}$ (coefficients of Eqs. 2 and 3) with the lag 1 (one) but did not get any short run causality neither from military expenditure to GDP growth nor from GDP growth to military expenditure at $5 \%$ level of significance, values are shown in Table 2.

The Table 3 denotes that we cannot reject the null hypothesis of no cointegration, but still we can illustrate the existence of cointegration from the significance test of ECTs. From the significance test of ECTs we get at least one variable has long run association with other, and that relationship is positive $\{0.1468$ (Eq. 4)\}.

\section{Causality test under VECM- Pakistan equations}

$$
\Delta \mathrm{GDP}_{\mathrm{t}}=\alpha+\beta_{1}+(0.1468) \mathrm{MILE}+\mathrm{e}
$$

Table 2 Result of Short-run Ganger Causality test- India

\begin{tabular}{lcc}
\hline Excluded & Chi-sq & Probability \\
\hline Dependent variable 'GDP growth' & & \\
D(Military Expenditure) & 9.3406 & 0.9976 \\
$\begin{array}{l}\text { Dependent variable 'Military Expenditure' } \\
\text { D(GDP growth) }\end{array}$ & 0.0185 & 0.8917 \\
\hline
\end{tabular}


Table 3 Result of Cointegration test Pakistan

\begin{tabular}{clll}
\hline Hypothesized No of CE & Trace Statistics & Critical Value & Probability \\
None & 14.4583 & 20.2618 & 0.2591 \\
At most 1 & 5.74953 & 9.16454 & 0.2110 \\
Hypothesized No of CE & Max-Eigen Statistics & Critical Value & Probability \\
None & 8.7088 & 15.8921 & 0.0012 \\
At most 1 & 5.7495 & 9.16454 & 0.2110 \\
\hline
\end{tabular}

$$
\begin{aligned}
& \Delta \mathrm{GDP}_{\mathrm{t}}=\alpha+\sum_{\mathrm{i}=1}^{\mathrm{m}} \beta_{\mathrm{i}} \Delta \mathrm{GDP}_{\mathrm{t}-\mathrm{i}}+\sum_{\mathrm{i}=1}^{\mathrm{n}} \gamma_{\mathrm{i}} \Delta \mathrm{MILE}_{\mathrm{t}-\mathrm{i}}+\delta \mathrm{ECT}+\mathrm{u}_{\mathrm{t}} \\
& \Delta \mathrm{MILE}_{\mathrm{t}}=\alpha+\sum_{\mathrm{i}=1}^{\mathrm{q}} \zeta_{\mathrm{i}} \Delta \mathrm{MILE}_{\mathrm{t}-\mathrm{i}}+\sum_{\mathrm{i}=1}^{\mathrm{s}} \lambda_{\mathrm{i}} \Delta \mathrm{GDP}_{\mathrm{t}-\mathrm{i}}+\phi \mathrm{ECT}+\mathrm{u}_{\mathrm{t}}
\end{aligned}
$$

Equation (5) tests the causality from military expenditure to GDP and the Eq. (6) tests the causality from GDP to military expenditure for Pakistan.

We have jointly tested $\sum_{i=1}^{n} \gamma_{i} M_{L L E}$ (coefficients of Eqs. 5 and 6) with all the lag 1 (one) but we did not get any short run causality neither from military expenditure to GDP growth nor from GDP growth to military expenditure at 5\% level of significance, values are shown in Table 4.

According to the result shown in the Table 5 at $5 \%$ level of significance we can reject the null hypothesis that "there is no Cointegration in this model" in both trace test and maximum-eigen value test. Both tests also indicate that there is 1 positively $\{17.04$ (Eq. 7)\} cointegrated equation at $5 \%$ level of significance.

\section{Causality test under VECM- China equations}

$$
\begin{aligned}
& \Delta \mathrm{GDP}_{\mathrm{t}}=\alpha+\beta_{1}+(17.04) \mathrm{MILE}+\mathrm{e} \\
& \Delta \mathrm{GDP}_{\mathrm{t}}=\alpha+\sum_{\mathrm{i}=1}^{\mathrm{m}} \beta_{\mathrm{i}} \Delta \mathrm{GDP}_{\mathrm{t}-\mathrm{i}}+\sum_{\mathrm{i}=1}^{\mathrm{n}} \gamma_{\mathrm{i}} \Delta \mathrm{MILE}_{\mathrm{t}-\mathrm{i}}+\delta \mathrm{ECT}+\mathrm{u}_{\mathrm{t}} \\
& \Delta \mathrm{MILE}_{\mathrm{t}}=\alpha+\sum_{\mathrm{i}=1}^{\mathrm{q}} \zeta_{\mathrm{i}} \Delta \mathrm{MILE}_{\mathrm{t}-\mathrm{i}}+\sum_{\mathrm{i}=1}^{\mathrm{s}} \lambda_{\mathrm{i}} \Delta \mathrm{GDP}_{\mathrm{t}-\mathrm{i}}+\phi E C T+\mathrm{u}_{\mathrm{t}}
\end{aligned}
$$

Equation (8) tests the causality from military expenditure to GDP and the Eq. (9) tests the causality from GDP to military expenditure for China.

We have jointly tested $\sum_{\mathrm{i}=1}^{\mathrm{n}} \gamma_{\mathrm{i}} \mathrm{MILE}_{\mathrm{t}-\mathrm{i}}$ (coefficients of Eqs. 8 and 9) with all the lags-1 (one) and we got not short run causality from military expenditure to GDP growth also

Table 4 Result of short-run Ganger Causality test- Pakistan

\begin{tabular}{lcc}
\hline Excluded & Chi-sq & Probability \\
\hline Dependent variable 'GDP growth' & & \\
D(Military Expenditure) & 1.1171 & 0.2905 \\
$\begin{array}{l}\text { Dependent variable 'Military Expenditure' } \\
\text { D(GDP growth) }\end{array}$ & 0.0029 & 0.9569 \\
\hline
\end{tabular}


Table 5 Result of Cointegration test- China

\begin{tabular}{llll}
\hline Hypothesized No of CE & Trace Statistics & Critical Value & Probability \\
None & 42.1769 & 18.3977 & 0.0000 \\
At most 1 & 12.2788 & 3.84146 & 0.0005 \\
Hypothesized No of CE & Max-Eigen Statistics & Critical Value & Probability \\
None & 29.8980 & 17.1476 & 0.0004 \\
At most 1 & 12.2788 & 3.84146 & 0.0005 \\
\hline
\end{tabular}

from GDP growth to military expenditure at 5\% level of significance, values are described in Table 6.

\section{Findings}

The relationship between military expenditure and GDP growth is a matter of contest in economic literature and the finding of such study vary from region to region, country to country. However, the goal of this study is to find short and long run relationship between GDP growth and military expenditure for three emerging country of south Asia using Ganger causality and Cointegration test. Finally, we found some interesting result for the countries. Interestingly, the study got positive long run relationship and long-run causality from military to GDP growth at 5\% level of significance, but no short run relationship for all the three countries, though the degree of relationship between variables are different from one another.

\section{Conclusion}

The study of peace economics has started its journey few decades ago and the journey will be continued as long as the economics exist in the planet. The researchers of economic literature normally research on his territory where he belongs, and the result of these research vary from geography to geography. Getting different result for different countries is a neo natural matter, indeed a country's economic factors are largely affected by its external and internal factors for this reason in spite of working on same topic every researcher gets different results. We are optimistic that this type of empirical observation can be a valuable source for policy makers of India Pakistan and China, and can be a helpful guide for those who wants to investigate the relationship for his country even who wants to reinvestigate our finding using different econometrical approaches. In future anyone can run his research adding other related variables with these variables or can justify the relationship of other important government spending with GDP growth of a country.

Table 6 Result of short-run Ganger Causality test-China

\begin{tabular}{lcc}
\hline Excluded & Chi-sq & Probability \\
\hline Dependent variable 'GDP growth' & & \\
D(Military Expenditure) & 0.6514 & 0.4196 \\
$\begin{array}{l}\text { Dependent variable 'Military Expenditure' } \\
\text { D(GDP growth) }\end{array}$ & 1.5338 & 0.2155 \\
\hline
\end{tabular}




\section{Abbreviations}

ADF test: Augmented Dickey-Fuller test; ARDL: Autoregressive Distributed Lag Model; ECT: Error Correction Term; EU: European Union; GDP: Gross Domestic Products; SIPRI: Stockholm International Peace Research Institute; VECM: Vector Error Correction Model

\section{Acknowledgements}

An earlier version of the article was presented in before my undergraduate thesis defense board arranged by department of Economics and Banking, International Islamic University Chittagong. We acknowledge the contribution of the person who encourage me in research, who conducted the E-views learning sessions, and the professors who gave us their critical reviews.

\section{Authors' contributions}

MHR contributed through collecting data, writing manuscript, doing econometric analyses, citing the scholars' works. ZA contributed through providing guide for writing manuscript, arranging workshop for getting a clear idea about econometrical analysis and citation, providing time to time corrections on initial drafts and providing inputs to make the thesis publishable. Both authors read and approved the final manuscript.

\section{Funding}

The research was conducted by authors own finance.

\section{Availability of data and materials}

All the data and relevant material are available to the first author. For any research purpose, he will send the data in excel format through email upon request.

\section{Competing interests}

The authors declare that they have no competing interests.

\section{Author details}

${ }^{1}$ Graduate of Department of Economics \& Banking, International Islamic University Chittagong, Chattogram, Bangladesh. ${ }^{2}$ Faculty, Department of Economics \& Banking, International Islamic University Chittagong, Chattogram, Bangladesh.

Received: 6 January 2019 Accepted: 23 May 2019

Published online: 21 June 2019

\section{References}

Abu-qarn, A.S. 2010. The defence-growth nexus revisited: Evidence from the Israeli-Arab conflict. Defence and Peace Economics 21 (4): 291-300

Adams, F.G., J.R. Behrman, and M. Boldin. 1991. Government expenditures, defense, and economic growth in the LDCs: A revised perspective. Conflict Management and Peace Science 11 (2): 19-35.

Alexander, W.R.J. 1990. The impact of defence spending on economic growth*: A multi-sectoral approach to defence spending and economic growth with evidence from developed economies. Defence and Peace Economics 2 (1): 39-55.

Asseery, A.A. 1996. Evidence from time series on militarizing the economy: The case of Iraq. Applied Economics 28 (10): $1257-1261$.

Atesoglu, H.S. 2002. Defense spending promotes aggregate output in the United States--evidence from Cointegration analysis. Defence and Peace Economics 13 (1): 55-60.

Ball, N. 1983. Defense and development: A critique of the Benoit study. Economic Development and Cultural Change 31 (3): $507-524$.

Benoit, E. 1973. Defense and economic growth in developing countries.

Benoit, E. 1978. Growth and defense in developing countries. Economic Development and Cultural Change 26 (2): 271-280.

Chen, C.-H.J.J.o.E.S. 1993. Causality between defence spending and economic growth: the case of mainland China. Journal of Economic Studies. London. Mimeo 20 (6).

Dakurah, A.H., S.P. Davies, and R.K. Sampath. 2001. Defense spending and economic growth in developing countries: A causality analysis. Journal of Policy Modeling 23 (6): 651-658.

Deger, S. 1986. Economic development and defense expenditure. Economic Development and Cultural Change 35 (1): 179-196.

Deger, S., and R. Smith. 1983. Military expenditure and growth in less developed countries. Journal of Conflict Resolution 27 (2): 335-353.

Dicle, B., and M.F. Dicle. 2010. Military spending and GDP growth: Is there a general causal relationship? Journal of Comparative Policy Analysis 12 (3): 311-345.

Dunne, J.P., E. Nikolaidou, and R. Smith. 2002. Military spending, investment and economic growth in small industrialising economies. South African Journal of Economics 70 (5): 789-808.

Dunne, P., and D. Vougas. 1999. Military spending and economic growth in South Africa: A causal analysis. Journal of Conflict Resolution 43 (4): 521-537.

Faini, R., P. Annez, and L. Taylor. 1984. Defense spending, economic structure, and growth: Evidence among countries and over time. Economic Development and Cultural Change 32 (3): 487-498.

Farzanegan, M.R. 2014. Military spending and economic growth: The case of Iran. Defence and Peace Economics 25 (3): $247-269$.

Feridun, M., B. Sawhney, and M. Shahbaz. 2011. The impact of military spending on economic growth: The case of North Cyprus. Defence and Peace Economics 22 (5): 555-562.

Gupta, S., L. De Mello, and R. Sharan. 2001. Corruption and military spending. European Journal of Political Economy 17 (4): $749-777$.

Khalid, M.A., and A.B. Mustapha. 2014. Long-run relationship and causality tests between military expenditure and economic growth in India. The Economics and Finance Letters 1 (6): 49-58.

Kollias, C., G. Manolas, and S.-M. Paleologou. 2004a. Defence expenditure and economic growth in the European Union: A causality analysis. Journal of Policy Modeling 26 (5): 553-569. 
Kollias, C., C. Naxakisb, and L. Zarangasb. 2004b. Defence spending and growth in Cyprus: A causal analysis. Defence and Peace Economics 15 (3): 299-307.

Lim, D. 1983. Another look at growth and defense in less developed countries. Economic Development and Cultural Change 31 (2): 377-384.

Park, K.Y. 1993. Pouring new wine into fresh Wineskins': Defense spending and economic growth in LDCs with application to South Korea. Journal of Peace Research 30 (1): 79-93.

Ram, R. 1986. Government size and economic growth: A new framework and some evidence from cross-section and timeseries data. The American Economic Review 76 (1): 191-203.

Ram, R. 1995. Defense expenditure and economic growth. Handbook of Defense Economics 1: 251-274.

Shahbaz, M., T. Afza, and M.S. Shabbir. 2013. Does defence spending impede economic growth? Cointegration and causality analysis for Pakistan. Defence and Peace Economics 24 (2): 105-120.

Smith, D., and R. Smith. 1980. Military expenditure, resources and development. University of London, Birkbeck College Discussion Paper (87): 37-44.

Yildirim, J., S. Sezgin, and N. Öcal. 2005. Military expenditure and economic growth in middle eastern countries: A dynamic panel data analysis. Defence and Peace Economics 16 (4): 283-295.

\section{Publisher's Note}

Springer Nature remains neutral with regard to jurisdictional claims in published maps and institutional affiliations.

Submit your manuscript to a SpringerOpen ${ }^{\odot}$ journal and benefit from:

- Convenient online submission

- Rigorous peer review

- Open access: articles freely available online

- High visibility within the field

- Retaining the copyright to your article

Submit your next manuscript at $\boldsymbol{\nabla}$ springeropen.com 